АКТУАЛЬНІ НАПРЯМИ ЗАБЕЗПЕЧЕННЯ ФОРМУВАННЯ ЗДОРОВ'ЯЗБЕРЕЖУВАЛЬНОЇ КОМПЕТЕНТНОСТІ СТУДЕНТІВ ЗАКЛАДІВ ВИЩОЇ ІНЖЕНЕРНО-ПЕДАГОГІЧНОЇ ОСВІТИ

\title{
THE HOT PROSPECTS FOR HEALTH SAVING COMPETENCE FORMATION PROVIDING OF HIGHER EDUCATIONAL PEDAGOGICS-ENGINEER ESTABLISHMENTS STUDENTS
}

З огляду на специфрічні вимоги до освітнього процесу вищої школи з метою фрормування здоров'язбережувальної компетентності майбутніх фахівців, з'ясовано визначен науковцями шляхи підвищення есрективності орормування здоров'язбережувальної компетентності майбутніх фрахівців (забезпечення усвідомлення особистістю необхідності дбати про власний стан здоров'я і здоров'я оточуючих; фрормування цінностей фозичного розвитку (рухової активності); оволодіння теоретичною базою валеологіч ної науки (валеопедагогіки); використання можливостей профессійної підготовки (різних видів діяльності, напрямів підготовки тощо) для створення умов сприяння здоровому способу життя студентської молоді). 3 урахуванням професійних фуннцій представника інженерно-педагогічної галузі з'ясовано роль і структуру його здоров'язбережувальної компетентності як комплексної характеристики, що має загальні та спеціальні компетентності (здатності піклуватися про стан фрізичного, психічного, соціального йдуховного здоров'я). Аналіз процесу профресійної підготовки майбутнього фрахівия інженерно-педагогічної галузі дав змогу схарактеризувати потенчійні можливості чинної системи підготовки майбутнього інженера-педагога для формування його здоров'язбережувальної компетентності. З'ясовано, що система професійної підготовки фрахівия, покликаного виконувати педагогічні фрункції з професійної освіти виробничих кадрів, потребує теоретико-методичного забезпечення формування його здоров'язбережувальної компетентності. Автором окреслено напрями забезпечення формуування здоров'язбережувальної компетентності студентів закладів вищої інженерно-педагогічної освіти, що містяться в можливостях змісту й організації навчальної діяльності студентів; потениіалі виховної діяльності зі студентами; різних формах організаціі позааудиторної діяльності студентів; можливостях організації самостійної діяльності студентів; потенціалі педагогічних і виробничих практик; змісті науково-дослідно діяльності студентів. З'ясовано, що визначені напрями вимагають теоретичного обґрунтування й розроблення методичного забезпечення їх реалізації. Автором схарактеризовано окремі з визначених напрямів, ураховуючи їх актуальність.

Ключові слова: здоров'язбережувальна компетентність фрахівия, срормування, профе - сійна підготовка, майбутній інженер-педагог, заклад вищої інженерно-педагогічної освіти, напрями.

Taking into account the specific requirements for the higher school educational process with the health saving competence formation aim of future specialists it is determinate the scientists ways for efficiency health saving competence formation increase of future specialists (providing the realization of necessity caring of health personality and public health; physical development values formation (moving activity); have theoretical base of valeological science knowledge (valeological education); the usage of professional preparation possibilities (different types of activity, prospects of preparation and others) for favorable living environment conditioning for the healthy way of students' life) are found out. Having regard to the professional functions of the pedagogics-engineer industry representative is found out a role and structure of their health saving competence as a complex description that has general and special competences (capabilities to care of the physical, psychical, social and spiritual health). The analysis of professional preparation process for future pedagogics-engineer specialist was treated by characteristic of potential possibilities for the preparation system of future teacher-engineer for their health saving competence formation. It is found out that the professional preparation system for the specialist who serves a vocational education and training pedagogical functions needs the theoretical and methodical providing of their health sav ing competence formation. The author difined providing health saving competence formation prospects for the students of higher pedagog ics-engineer educational establishments that are contained possibilities for maintenance and educational students activity organization; potential of educator activity with students; different organization forms of class out students activity; possibilities of independent activity students organization; potential of pedagogical and productive practices; the contents of research students activity. It is found out that certain prospects require a theoretical ground and methodical realization providing development. The author was characterized separate prospects taking into account hot ones.

Key words: the specialist's health saving competence, formation, professional preparation, future teacher-engineer, higher pedagogicsengineer educational establishment, prospects.
Постановка проблеми в загальному вигляді. На сучасному етапі перебудови вищої освіти в Україні актуальною проблемою $€$ визначення загальної мети підготовки фрахівця до виконання профресійних фрункцій. На підставі пріоритетності компетентнісного підходу до реалізації стратегічних завдань вищої освіти в нормативних документах, що регламентують здійснення такої освіти в навчальних закладах, реалізація запланованої мети має бути представленою в чітко визначених 
результатах, якими є сфрормовані компетентності фахівця. Серед таких компетентностей як здатностей фрахівця виконувати належним чином покладені на нього фрункції громадянина суспільства, держави і представника певної професійної діяльності однією з важливих визначається компетентність, яка забезпечує готовність людини піклуватися про власний стан фрізичного, психічного, соціального та духовного здоров'я. Змістове наповнення такої компетентності, що визначається як здоров'язбережувальна, залишається до кінця не з'ясованим питанням, до дослідження якого звертаються сучасні науковці.

Аналіз останніх досліджень і публікацій. Проблемі здоров'язбережувальної компетентності особистості присвячено наукові дослідження Т. Андрющенко, О. Антонової, Н. Поліщук, Ю. Бойчука, М. Гончаренко, А. Турчинова, зокрема її фрормуванню у майбутніх фахівців різних спеціальностей - Н. Башавець, Д. Вороніна, А. Воропаєвої, Н. Завидівської, Є. Кочерги, І. Мельничук, О. Міхеєнка, Ю. Мусхаріної, О. Шукатки та ін.

Виділення не вирішених раніше частин загальної проблеми. Незважаючи на наукові пошуки дослідників, нез'ясованими залишаються напрями забезпечення фрормування здоров'язбережувальної компетентності студентів закладів вищої інженерно-педагогічної освіти. Проте у зв'язку з підвищенням вимог до організації професійно-технічної освіти саме до викладачів, покликаних забезпечувати підготовку виробничих кадрів, висуваються вимоги щодо володіння здоров'язбережувальними технологіями зокрема.

Метою статті $€$ окреслення й обґрунтування актуальних напрямів фрормування здоров'язбережувальної компетентності студентів закладів вищої інженерно-педагогічної освіти.

Виклад основного матеріалу. І. Мельничук визначає, що на сучасному етапі розвитку суспільства висуваються певні специфрічні вимоги до освітнього процесу вищої школи з метою фрормування здоров'язбережувальної компетентності майбутніх фрахівців: формування в студентів ціннісного ставлення до власного здоров'я і здоров'я тих, стосовно кого вони виконуватимуть свої функції в майбутній профресійній діяльності (особливо актуальним це положення $€$ для представників соціономічного типу профресій); сприяння всебічному фрізичному розвитку й досягненню високого рівня загальної рухової підготовки індивіда (збереження та зміцнення рухової активності $€$ цінним фрактором для життєдіяльності загалом і для ефрективності виконання профресійних фрункцій зокрема); основою впливу на формування здорового способу життя вважати перенесення відповідних знань, умінь і навичок з однієї сфрери діяльності (наприклад, профресійної підготовки) в іншу (у майбутню професійну діяльність); комплексне фрормування здорового способу життя, який ураховує всі можливості освітнього процесу, а також індивідуальні особливості особистості; необхідність удосконалення самого процесу формування здоров'язбережувальної компетентності незалежно від професійного спрямування підготовки студентів тощо [7].

У зв'язку 3 цим основні зусилля 3 пошуку шляхів підвищення ефективності формування здоров'язбережувальної компетентності майбутніх фрахівців науковці пов'язують із таким:

1) впливом на особистість з метою забезпечення її усвідомлення необхідності дбати про власний стан здоров'я і здоров'я оточуючих (через фрормування інтересу, потреби, мотивації до цих процесів) з опорою й урахуванням індивідуальних особливостей і можливостей кожного;

2) приділенням особливої уваги фрормуванню в студентів цінностей фрізичного розвитку, що пов'язується $з$ руховою активністю;

3) забезпеченням фрахівця теоретичною базою валеологічної науки (валеопедагогіки), засади якої він має використовувати в подальшій життєдіяльності загалом і професійній діяльності зокрема [1];

4) залучення всіх можливостей професійної підготовки (різних видів діяльності, напрямів підготовки тощо) для створення умов сприяння здоровому способу життя студентської молоді (включаючи профрілактичні, організаційні напрями діяльності) [3].

Здоров'язбережувальна компетентність визначається науковцями як комплексна характеристика, котра має загальний рівень (загальні компетентності), які є основою для життєдіяльності людини в сучасному суспільстві, а також спеціальний рівень (спеціальні компетентності). Такі компетентності стосовно фрахівця інженерно-педагогічної галузі зумовлені професійними фрункціями, сорормованість яких $€$ підґрунтям для еорективного, оптимального здійснення професійної діяльності. Первинними щодо процесу формування здоров'язбережувальної компетентності фрахівця $€$ позитивно сприйняті й особистісно усвідомлені загальні компетентності, що створюють підґрунтя для фрормування спеціальних компетентностей. Сорормованість відповідних знань, умінь і навичок студентів 3 організації здоров'язбережувальної діяльності під час їхньої професійної підготовки в закладі вищої освіти (далі - ЗВО) створює особистісно ціннісну теоретико-практичну основу для перенесення стійких навичок у сфреру майбутньої професійної діяльності як стосовно власної особистості, так і щодо інших, насамперед вихованців закладів профресійно-технічної освіти.

Проведений аналіз процесу професійної підготовки майбутнього фрахівця інженерно-педагогічної галузі засвідчив, що чинна система підготовки містить і передбачає такий напрям, як формування 
його здоров'язбережувальної компетентності, який потребує теоретико-методичного забезпечення. Так, визначено основні напрями фрормування здоров'язбережувальної компетентності інженера-педагога:

1) можливості змісту й організації навчальної діяльності студентів (використання потенціалу навчальних нормативних і вибіркових дисциплін (фахових, педагогічних); дисципліни «фрізичне виховання»);

2) потенціал виховної діяльності зі студентами (організація кураторами, представниками студентського самоврядування виховної роботи зі здоров'язбереження зі студентами у 3ВО, гуртожитках тощо; організація спортивних культурномасових заходів) [2];

3) різні форми організації позааудиторної діяльності студентів (організація культурно-масових заходів валеологічного і здоров'язбережувального спрямування, групових та індивідуальних заходів просрілактичного характеру тощо);

4) можливості організації самостійної діяльності студентів (активна участь студентів у суспільно корисній, волонтерській діяльності здоров'язбережувального спрямування, розроблення проектів, кейсів щодо виробничих технологій, планування трудового процесу тощо);

5) потенціал педагогічних і виробничих практик (організація здоров'язбережувальної діяльності студентів під час виробничої й педагогічної практики на базах практики);

6) зміст науково-дослідної діяльності студентів (розширення тематики наукових досліджень валеологічного, здоров'язбережувального змісту 3 поглиблення критичного мислення студентів щодо актуальних проблем здоров'язбереження, опанування методологією валеопедагогіки тощо).

Отже, визначені напрями вимагають теоретичного обґрунтування й розроблення методичного забезпечення їх реалізації. Звернемося до характеристики окремих із визначених напрямів, ураховуючи їх актуальність.

Проведений аналіз програм підготовки студентів інженерно-педагогічних спеціальностей дав змогу виявити й проаналізувати навчальні дисципліни, зміст яких передбачає орормування загальних і спеціальних компетентностей здоров'язбережувальної компетентності інженера-педагога. Проведений аналіз навчального плану підготовки студентів освітньо-кваліфрікаційного рівня «бакалавр» зі спеціальностей «Профресійна освіта. Нафтогазова справа», «Профресійна освіта. Економіка», «Профресійна освіта. Транспорт» тощо дав можливість виявити дисципліни, у змісті яких є елементи, спрямовані на забезпечення здоров'язбережувальної компетентності. Так, із перших днів навчання студенти опановують дисципліну «Вступ до фраху», провідною метою якої є введення студентів у світ майбутньої професії; формування уявлень про професійні фрункції, покладені суспільством на представника цієї дуальної профресії; її місце й роль у суспільстві; вимоги, яким повинен відповідати майбутній фрахівець, щоб належно виконувати свої професійні фрункції. Однією з таких вимог $є$ вимога до фрізичного та психічного стану здоров'я фрахівця. Із цього приводу варто акцентування уваги студентів на важливості усвідомлення цінності власного здоров'я, без чого неможливим виявляється й реалізація суспільних і профресійних функцій.

3 першого семестру навчання упродовж трьох років передбаченою для студентів $є$ дисципліна «Фізичне виховання», яка потребує перебудови змісту у зв'язку із сучасними можливостями й технологіями. Так, В. Столяров [13] у фрізичному вихованні як навчальній дисципліні виділяє три блоки: фрормування знань, мотивації, умінь і навичок, які виявляються в поведінці, способі (стилі) життя. До основних компонентів фрізичної культури особистості і здорового способу життя, тобто тієї мети, яка стоїть перед кафедрами фрізичного виховання 3ВО, науковець зараховує рівень знань про організм, про засоби впливу на нього й методику їх застосування; ставлення особистості до свого тіла як до цінності; цілеспрямована діяльність із підтримки в нормі й удосконалення свого фрізичного стану, здоров'я, статури, фрізичних якостей і рухових здібностей; цінності, які особистість пов'язує 3 тілом, і реалізовані на практиці ідеали, норми, зразки поведінки, пов'язані з турботою про фрізичний стан; ступінь орієнтації на цю турботу і прагнення надавати допомогу іншим людям у їхньому оздоровленні та фрізичному вдосконаленні з наявністю для цього відповідних знань, умінь і навичок.

Варто відзначити, що така дисципліна, за наказами Міністерства освіти і науки України, вже не є нормативною й обов'язковою. Визначення її обсягу і змісту, а також шляхів забезпечення покладається на кожний навчальний заклад, ураховуючи визнану автономність закладів. 3 метою забезпечення викладання фрізичного виховання у ЗВО на належному рівні Міністерством освіти і науки запропоновано такі базові моделі для вирішення цього питання (без претензії на вичерпність) або різні форми їх поєднання [11]:

- секційну, що передбачає створення широкої мережі як спеціалізованих спортивних, так і загальнооздоровчих секцій, гуртків, клубів, які працюють за фріксованим розкладом у вільний від основних навчальних занять час (наприклад, у другу зміну для студентів, які мають навчальні заняття в першій половині дня);

- профресійно орієнтовану, що зумовлює розроблення комплексних програм із фрізичного виховання, які орієнтовані на особливості майбутньої профресії (учитель, лікар, офрісний 
працівник, програміст тощо). Альтернативними варіантами відвідування таких програм можуть бути суто спортивні секції, військово-прикладні секції (з орієнтуванням як юнаків, так і дівчат на досягнення вимог до вступу на програми військової підготовки), військово-медична підготовка 3 елементами загальносрізичної підготовки;

- mрадиційну, яка передбачає збереження фрізичного виховання як обов'язкової дисципліни 3 нарахуванням за неї кредитів, отриманням студентами заліків і включенням до розкладу занять із наданням студентам можливості як відвідувати групові заняття, так і займатися індивідуально в спортивних секціях та оздоровчих гуртках, клубах, програмах тощо за індивідуальним вибором;

- індивідуальну, спрямовану на закріплення за кожним студентом працівника кафедри фрізичного виховання або іншого спеціалізованого підрозділу, який виконує роль тьютора з питань оздоровлення та фрізичного розвитку, рекомендує певні види фрізичної активності (як спеціально організовані, так і самостійні), розробляє індивідуальну програму фрізичного розвитку, зокрема, у спортивних та оздоровчих секціях, гуртках, клубах або під час відвідування лекторіїв зі збереження здоров'я, планування родини тощо. Дві-три обов'язкові зустрічі зі студентом упродовж навчального року дадуть можливість більш м'яко мотивувати студента до фрізичної активності.

Як зазначає Ю. Мусхаріна [8], із багатьох навчальних дисциплін саме «фізичне виховання» вирізняється широким спектром впливу на людину, що спроможне водночас фрормувати не тільки біологічну структуру людини, а і її психологічну й моральну цінність: стимулювання фрізичної працездатності супроводжується, як правило, оздоровчими ефектами; використання різноманітних фрізичних вправ і процедур дає змогу здійснювати психологічне розвантаження особистості; систематичні заняття фрізичними вправами зміцнюють здоров'я, підвищують нервово-психічну стійкість до емоційних стресів, підтримують фрізичну й розумову працездатність, сприяють підвищенню успішності тих, хто навчається.

Отже, дисципліна «Фізичне виховання» потребує ресрормації у зв'язку з наявними потенційними можливостями для розширення змісту занять фрізичними вправами й упровадження валеологічних знань, обрання більш ефективних методів забезпечення інтересу й потреби студентів у здоров'язбережувальній діяльності. Варто відзначити, що для реалізації цього напряму незайвим буде вивчення й використання досвіду розвинених країн в організації фрізичного виховання студентської молоді.

Аналіз змісту блоку педагогічних дисциплін («Теорія і методика виховної роботи», «Методологічні засади професійної освіти», «Основи корекцій- ної педагогіки») дав змогу виявити можливості для фрормування компонентів здоров'язбережувальної компетентності, що потребують конкретизації, розширення, ураховуючи зміст компетентності, що фрормується. Безперечно, наявний зміст дисциплін не може забезпечити повною мірою фрормування здоров'язбережувальної компетентності студентів. Наявною $€$ потреба в розробленні додаткових спецкурсів, у змісті яких має бути передбачено теоретичне і практичне підґрунтя для фрормування окремих загальних компетентностей здоров'язбережувальної компетентності, що сприяють фрізичному, соціальному, психічному, духовному здоров'ю. Окрему проблему становить розроблення змісту курсів, спрямованих на забезпечення сорормованості спеціальних компетентностей здоров'язбережувальної компетентності, зумовлених профресійними функціями фрахівця інженерно-педагогічної галузі (проектувальної, організаційної, технологічної, дослідницької, виховної).

Створення теоретичного підґрунтя завдяки валеологічній підготовці студентів передбачає пошук шляхів, напрямів, фрорм і методів роботи із залучення студентів до спеціально організованої здоров'язбережувальної діяльності під час виховної діяльності: залучення студентів до активної участі в змістовному дозвіллі; використання потенціалу суспільно корисної, волонтерської діяльності тощо. Так, науковцями визначено пріоритетність реалізації рухової активності студентів у профресійній підготовці. Безперечно, позитивну роль у фрормуванні й зміцненні здоров'я відіграють адекватні фрізичні навантаження. Науковці відзначають, що в сучасному житті все більше занять фрізичними вправами спрямовано не на досягнення високих результатів, а на підвищення їх оздоровчого впливу [9].

Науковцями доведено, що активне залучення особистості до здоров'язбережувальної діяльності передбачає наявність позитивного особистісного ставлення до неї, котре не формується спонтанно й не успадковується. Воно набувається особистістю в процесі самої діяльності й ефективно розвивається під час засвоєння знань і накопичення творчого досвіду, пов'язаного з проявом ініціативи та активності в педагогічному процесі.

Так, психологами доведено, що розумова працездатність невіддільна від загального стану здоров'я й рухової активності. У віці 17-20 років, коли завершується фрормування організму, його вегетативних функцій, дії фрізичних вправ $€$ найбільш результативними. У віці 20-29 років досягає свого найвищого рівня одна 3 найважливіших для діяльності людини якостей - витривалість. У «студентському» віці відбувається найактивніший розвиток і відносна стабілізація психофрізіологічних фрункцій, завершується основний цикл 
соматичного фрормування людини, відбувається становлення інтелекту, його цілісності і структури, яку організує мислення. Навчання, що супроводжується постійною розумовою працею, визначає високий загальний тонус інтелекту. У цей період фрізичне виховання стає найважливішим засобом загартування організму та біологічною основою для ефективного процесу пізнавальної діяльності; тренована мускулатура допомагає нервовій системі долати розумові навантаження.

3 огляду на таке положення щодо статусу фрізичного виховання як навчальної дисципліни під час професійної підготовки фрахівців у системі вищої освіти, дещо заспокійливим є той усвідомлений фракт, що виключно навчальною дисципліною можливості фрізичного виховання студентів у ЗВО не обмежуються. Так, констатуючи недостатність передбачених аудиторних занять фрізичним вихованням у ЗВО, В. Стадник розглянув питання науково-практичної проблематики забезпечення належного рівня позаакадемічної роботи з урахуванням сьогоднішніх тенденцій розвитку фрізичного виховання в системі вищої освіти [12].

Ураховуючи визначені відповідні сучасним тенденціям освіти пріоритетні напрями розвитку фрізичного виховання в системі вищої освіти (особистісна орієнтація; постійне підвищення ії̈ якості, оновлення змісту й форм організації навчальновиховного процесу, органічне поєднання всіх фрорм занять, запровадження освітніх інновацій), більшість дослідників зауважують, що успіх підготовки фрахових спеціалістів залежить від багатьох фракторів, одним із яких є заняття студентів у позанавчальний час. Безперечно, роль додаткових занять фрізичним вихованням постійно зростає, зважаючи на те що рівень культури студентів виявляється в їхньому вмінні раціонально, повною мірою використовувати вільний час [5]. Від того, як він використовується, залежить не тільки успіх у навчанні й загальному розвитку, а й стан здоров'я та повнота життєдіяльності студента. Через це позаакадемічна робота у фрізичному вихованні, зокрема, для оптимізації рухової активності завжди займала одну з провідних позицій, водночас виступаючи методом і навчання, і самовиховання.

Погоджуємося зі В. Стадником у тому, що недостатність системи фрізичного виховання у ЗВО для забезпечення оптимального психофрізичного стану студентів зумовлює необхідність комплексного поєднання академічних і позаакадемічних занять фрізичними вправами у вільний час. Таке використання всіх фрорм фрізичного виховання має забезпечити включення фрізичної культури в стиль життя студентів для досягнення оптимального рівня фрізичної активності. Науковець переконує в тому, що реалізація комплексного підходу до занять дасть змогу студентам забезпечити належний стан здоров'я [12, с. 35].
Зміст і фрорми позаакадемічних занять фрізичними вправами визначаються їх метою й завданнями, а вибір залежить від статі, віку, стану здоров'я та рівня фрізичної підготовленості студентів. До основних фрорм позаакадемічних занять студентів 3ВО науковці [10] зараховують такі:

- малі форми занять, що використовуються для оперативного управління фрізичним станом (фрізичні вправи в режимі дня). Унаслідок своєї короткочасності ці форми, як правило, не розв'язують завдань розвивального характеру: домашнє завдання 3 фрізичного виховання, ранкова гігієнічна гімнастика, гімнастика перед сном, фрізичні вправи протягом дня: фрізкультхвилинки, фрізкультпаузи, загартувальні процедури й заходи тощо;

- великі форми занять, тобто заняття тривалі, одно- та багатопредметні (комплексні) за змістом. Ці форми занять спрямовані на розв'язання завдань оздоровчо-реабілітаційного й рекреаційного характеру, які організуються у вільний від навчання час: самостійні заняття фрізичними вправами в місцях проживання студентів, психофрізична рекреація в заліково-екзаменаційний період, оздоровчо-рекреаційна діяльність.

Шляхи подолання наявних недоліків вбачаємо в упровадженні самостійних занять за вільним вибором студентів. Для цього має бути створена функціональна система позаакадемічної роботи 3 фрізичної культури: методики, технології, програми для досягнення позитивного ефекту у формуванні основ здоров'я. Найважливішими науковими проблемами при цьому є пошук оптимальних критеріїв підвищення якості безперервної загальної фрізкультурної освіти, спрямованої на фрормування таких загальнолюдських цінностей, як фрізичний, психічний і соціальний добробут, підвищення життєвих ресурсів студентської молоді, до найважливіших із яких належить здоров'я.

У цьому плані заслуговує на увагу безперервна загальна фрізкультурна освіта, яка передбачає розвиток інтересу, формування вмінь і навичок і пов'язаних із ними спеціальних знань, що являють собою основу для активного здоров'яформування в процесі позаакадемічних занять.

Особистісно орієнтований підхід до організації фрізичного виховання як напряму здоров'язбережувальної діяльності є актуальним і для студентської молоді. Так, фрахівці наголошують, що створення оптимальних умов організації процесу фрізичного виховання у ЗВО передбачає підхід, оснований на свободі вибору видів рухової активності [6].

У ході вивчення, аналізу та систематизації науково-методичної і спеціальної літератури встановлено, що під час розподілу студентів за групами за видами спорту варто враховувати його популярність, визначену шляхом анкетного опитування, 
можливості й стан спортивних споруджень, які має в розпорядженні вищий навчальний заклад, а також наявність фрахівців із видів спорту у викладацькому складі кафедри фрізичного виховання [4]. При цьому фрахівці загострюють увагу на тому, що одним із основних моментів під час організації занять груп за видами спорту за вільним вибором студентів $є$ визначення самих видів спорту, за якими можуть бути організовані заняття [4]

3 огляду на те що побудова занять за вибором студентів сприяє підвищенню мотивації відвідування занять та усвідомленому вибору активного способу життя, на нашу думку, існує необхідність попереднього вивчення уподобань студентів шляхом анкетування; просвіти й популяризація тих видів рухової активності, розвиток у яких майбутніх інженерів-педагогів може повною мірою забезпечуватися у ЗВО завдяки матеріальній базі, фрахівцям тощо, а також таких, що мають професійне значення для студентів. Так, зайняття волейболом, для якого характерними є різноманітні за координацією рухи, біг, стрибки, необхідними $є$ швидка реакція, гострота зору, точність, психічна стійкість, що мають професійно-прикладне значення, забезпечує сорормованість, зокрема, й профресійних характеристик інженера-педагога.

Висновки. Отже, виявлені актуальні напрями фрормування здоров'язбережувальної компетентності студентів - майбутніх інженерів-педагогів, закладені в змісті професійної підготовки й передбачені організацією навчальної, виховної, позааудиторної, самостійної, практичної та науково-дослідної діяльності студентів. Схарактеризовано можливості вдосконалення окремих із них (навчальної, виховної, позааудиторної й самостійної роботи).

Подальшого дослідження потребує проблема організації практичної та науково-дослідної діяльності студентів, спрямованої на фрормування здоров'язбережувальної компетентності студентів вищого інженерно-педагогічного навчального закладу, розроблення їх методичного забезпечення.

\section{БІБЛІОГРАФІЧНИЙ СПИСОК:}

1. Бойчук Ю.Д., Турчинов А.В. Сутність здоров'язбережувальної компетентності в контексті валеологічної парадигми. Проблеми інженернопедагогічної освіти: зб. наук. пр. 2015. № 48-49. URL: http://library.uipa.edu.ua/resources/problemi- inzhenerno-pedagogichnoji-osviti-zbirnik-naukovikhprats-vipusk-48-49.html.

2. Васильєва М.П. Особливості соціального виховання студентської молоді. Соціально-педагогічна діяльність у сорері дозвілля: проблеми і перспективи: мат-ли Наук.-практ. конф. (Харків, 06.12.2016). Харків: ХДАК, 2016. С. 36-37.

3. Васильєва М.П., Подберезський М.К. Технології соціально-педагогічної роботи зі студентською молоддю. Науковий часопис НПу імені М.П. Драгоманова. Київ: НПУ ім. М.П. Драгоманова, 2018. № 24. T. 1. С. 41-48.

4. Коник Г.А., Темченко В.А., Усова Т.Е. Учебные занятия по видам спорта как средство фрормирования мотивации к здоровому образу жизни у студентов высших учебных заведений. URL: http://lib. sportedu.ru/books/xxpi/2002N4/p41-45.htm.

5. Котов $€$., Хомич А., Касарда О. Програмування самостійних занять фрізичними вправами студентів вищих навчальних закладів. Фізичне виховання, спорт і культура у сучасному суспільстві. Луцьк, 2012. № 4 (20). С. 294-299.

6. Марченко О.Ю. Відношення студентів, які займаються та не займаються спортом, до занять фрізичним вихованням. Педагогіка, психологія та медико-біологічні проблеми. 2009. № 9. С. 88-91.

7. Мельничук І.М. Формування здоров'язбережувальної компетентності майбутніх бакалаврів сестринської справи як складової професійної компетентності. Науковий вісник МНУ імені B.О. Сухомлинського. Серія «Педагогічні науки». 2015. № 1 (48). С. 195-200.

8. Мусхаріна Ю.Ю. Формування культури здоров'я майбутнього вчителя фрізичної культури як важлива умова ефрективності оздоровлення підлітків. Проблеми інженерно-педагогічної освіти: зб. наук. пр. Харків: УІПА, 2011. № 30-31. С. 218-222.

9. Мусхаріна Ю.Ю., Чернобай С.О. Волейбол та емоційне здоров'я студентів педагогічного університету. Педагогіка, психологія та медико-біологічні проблеми фрізичного виховання і спорту. 2013. № 7. C. 34-38. URL: 10.6084/m9.figshare.735963.

10. Присяжнюк С.І. Фізичне виховання. Київ: ЦУЛ, 2008. 502 c.

11. Рекомендації щодо організації фрізичного виховання у вищих навчальних закладах: Лист МОН від 25.09.15 № 1/9-454.

12. Стадник В. Проблемне поле позаакадемічних занять фрізичним вихованням студентів ВНЗ. Молодіжний науковий вісник. 2013. С. 34-38.

13. Столяров В.И. Методологические принципы определения понятий в процессе научного исследования фризической культуры и спорта. Москва: ГЦОМФК, 1984. 67 с. 